\title{
Pastoral Care for Sunday School Children of Indonesian Church in Australia During Pandemic
}

\author{
Hans Peteryo Halim ${ }^{1}$, Yanto Paulus Hermanto ${ }^{2}$, Rubin Adi Abraham ${ }^{3}$ \\ ${ }^{1}$ Indonesian Mission Institute (IMI) Australia \\ ${ }^{2,3}$ Sekolah Tinggi Teologia Kharisma Bandung Indonesia
}

\begin{abstract}
During this pandemic of Covid-19 in 2020, supports and encouragement are needed in the society, especially in church. Therefore, pastoral service must keep running and serving the congregation. In this regard, the researcher is obliged to explore how Indonesian churches' pastoral care in Australia should continue, especially in Sunday school during the pandemic. The method used is literature and field research methods. From the results of this research, we obtain a clear picture of how pastoral care should continue and what the church can do to remain pastoral care in Sunday school. The most important thing is to have Sunday school teachers who can teach, guide, and lead their Sunday school children. Having a clear understanding of the children characteristic is also critical, as important as knowing how to run the online Sunday school service. Likewise, parent supports are essential for running the Sunday school as an online church service.
\end{abstract}

Keywords: Sunday school during pandemic, Covid-19, Indonesian church in Australia, Online church service

\section{INTRODUCTION}

$\mathrm{M}$ arch is a month when churches are starting to plan their Easter service, yet March 2020 is a month when almost every church cancelled their Easter plan. As the World Health Organization - WHO has established pandemic status in the Covid-19 virus. WHO is declaring the status following the rapid spread of the virus, which is impacting globally ${ }^{1}$. So, the Australian government is working on ways to suppress and break the chain of the spread of the virus, from providing health assistance to those affected to banning large numbers of associations. This tightening has had a profound impact on various sectors, ranging from workers who can no longer work in offices, the closure of borders between states and between countries. The social distancing is aiming the flat curves - engulfing the covid-19 virus transmission curve $^{2}$. So this has an impact on church worship as well as Sunday school worship.

In the pre-pandemic, Sunday school service activities were conducted face-to-face every Sunday, about an hour and a half of worship. The services run in two sessions, thirty to forty minutes of children gather together. Next, the rest of the children's time will be separated into classes based on their

\footnotetext{
${ }^{1}$ Gita Laras Widyaningrum, "WHO Tetapkan COVID-19 Sebagai Pandemi Global, Apa Maksudnya?," National Geographic Indonesia (2020).

2 Sof Andrikopoulos and Greg Johnson, "The Australian Response to the COVID-19 Pandemic and Diabetes - Lessons Learned," Diabetes Research and Clinical Practice (2020).
}

age until the time the children's parents finish the public service and pick up their children. For the first forty minutes, all the children will gather together to play, sing and praise God. Next, a Sunday school teacher will give a short sermon, about fifteen to twenty minutes. The next session, children will divide according to their age level into the classes and teachers who have prepared. In these classes, where the teaching and mentoring process is happening, children get a more in-depth explanation of the sermons delivered earlier in a language that is easier to understand. Also, children can ask and tell stories about what they are experiencing related to the sermons they listen. Besides, children can also perform activities that support existing teaching along with teachers, where teachers can provide support, and children can feel that support directly.

As both parents and teachers can teach children to enjoy the learning process by showing the positive side of every challenge and mistake that children face ${ }^{3}$. In addition to pastoring children, relationships with the children's parents are essential, as parents are the person who most often meets and interacts with children every day. In this case, parents are a person that children consider crucial in their lives. Thus, children will be less likely to do what is considered wrong by the person they consider essential ${ }^{4}$. Thus, when the parents come to pick up their children, the Sunday school leader can take some times to have a chat with the parents. Give some reports about how their children are behaving, and get some insight on how to manage their kids. Since most of the children, times are with their parents, and kids are staying with the Sunday school teacher only one to two hours a week.

In the pre-pandemic, pastoral care on Sunday school children in Indonesian churches in Australia is well implemented, although not without obstacles. One of the main problems is the language, as the daily teacher's language as not the same as the children daily language. This Bilingual circumstance is common in Indonesian families, or Indonesian churches in Australia. However, by face-to-face teaching, this problem can be overcome by using body language.

\footnotetext{
${ }^{3}$ Carol S. Dweck, "The Secret to Raising Smart Kids," Scientific American Mind (2007).

${ }^{4}$ Robert G. Crosby and Erin I. Smith, "Measuring Children's Church-Based Social Support: Development and Initial Validation of the Kids' Church Survey," Social Development 26, no. 2 (May 2017): 423-442, http://doi.wiley.com/10.1111/sode.12198.
} 
Based on the above description, the problem of this study is how Sunday school children can keep getting their spiritual needs during the covid-19 pandemic. The purpose of this research is to determine the right ways, methods, and strategies for church leaders to do pastoral care for Sunday school children in times of pandemic. Find solutions for the bilingual language, with teaching conditions that do not faceto-face, as well as the church's limited facilities and financial capabilities. So during this pandemic, Sunday school students can keep getting their spiritual needs, and their spiritual growth.

\section{RESEARCH METHODS}

The research methods that the author will use in writing this thesis are:

Literature research methodology. This method is to focus on using much literature, which aims to gain an in-depth understanding. Including what is pastoral care, who are Sunday school children, what is pandemic, and how to do pastoral care for Sunday school children during pandemics.

Field research methodology. This research method requires researchers to jump indirectly, feel, and observe what is happening in the field. The field research site for this research is an Indonesian church in Melbourne, Australia, named Place of Joy. The church has a congregation of between 150 and 200 congregations and has a Sunday school service known as Joy Kids. There are 30 students, with active teachers currently 16, ranging from students to parents of Sunday school children.

\section{RESULTS AND DISCUSSIONS}

\section{Pastoral of the Church of Indonesia in Australia}

Pastoral is a duty of service given by the Lord to those chosen as pastor. In the Bible, in the gospel of John 21:15-19, Jesus said three times to the apostle Peter, "Feed my sheep." With this commandment spoken three times, it means this commandment is a fundamental commandment to do, especially for people who have been chosen or chosen to be a pastor. A pastor has responsibility for several things: dodaskalous (teaching), piomenas (guiding), and episcopos (leading) ${ }^{5}$. In performing his or her pastoral duties, and a pastor must be humble. So, he or she can be able to be a good example and carry out each of his or her duties voluntarily ${ }^{6}$.

Teaching is one of the essential tasks a pastor has. Good teaching is distinct as that which leads to improved student progress. We describe effective teaching as that which leads to enhanced student accomplishment using outcomes that matter to their future success ${ }^{7}$. There are many ways a pastor can perform the role of a teacher in the church. Firstly, the pulpit is an excellent place to be used as a facility in teaching,

\footnotetext{
${ }^{5}$ Sadrak Kurang, "Dimensi Pelayanan Pastoral," Jurnal Jaffray (2005).

${ }^{6}$ Calvin Sholla Rupa', "Ciri Khas Seorang Gembala Berdasarkan Perspektif 1 Petrus 5:1-4,” Jurnal Jaffray (2016).

${ }^{7}$ Robert Coe et al., "What Makes Great Teaching?," Centre for Evaluation and Monitoring (2014).
}

by doing the exposure of the Bible, followed by concrete examples, so that the congregation can directly practise it. Second, through cell group forums. A pastor can visit the cell groups in his or her church to be able to provide more specific teaching according to the needs of the participants of the cell groups visited. For example, a group with the majority of participants are young people. Then the pastor can have a discussion that focuses on the needs of the youngster such as, the problem of a spouse living or finding work. It will be different when visiting a group that the majority are family. The discussion will be more to the needs of the family, such as child problems or the relationship between husband and wife.

Similarly, when the shepherd visits a Sunday school service, which must be separate from the public service in general. Third, bible study forum. Here the pastor can peel the truth of the Bible in more depth, explain the history of writing, to the original language of writing from a piece of the Bible verse. All of these activities are carried out with one final purpose, to bring the congregation to flourish and succeed in knowing and experiencing God personally. So the congregation can have faith firmly embedded in the knowledge of God.

As a shepherd to its sheep, guide and lead them to the pasture to eat, and calm water to drink. The church pastor is the one who is also guiding and leading the congregation to get their spiritual needs and spiritual development. A leader who can adapt dynamically and has practical leadership skills is the key needed to bring the organization he leads to growth and success $^{8}$. In carrying out the leadership function in the church, a pastor must always balance biblical teaching with its application contextually ${ }^{9}$. A leader who can lead dynamically and effectively over time, known as a transformational leader. The characteristics of such leaders are: first, the leader who exerts influence, one who is admired by his or her followers, and becomes an example for their lives. Secondly, this leader is a person who can inspire, motivation for the followers so that they can reach the organization goals. Third, this leader is one who can stimulate the intellectuals of his or her followers so that they can become more confident to bring out their creativity and innovation. This leader also stimulates the curiosity of his followers so that they dare to ask questions and be brave to move and not just stay in a habit. It rewards the success of its followers and rewards no punishment for a new idea that has failed. Fourth, this leader treats his followers unevenly because each person's needs vary. Understand every characteristic of person per person to accelerate personal development for each of his followers ${ }^{10}$.

A pastor is responsible for the spiritual development, growth of every congregation in his church. A church generally has

\footnotetext{
${ }^{8}$ Danièle Léger, "The Making of a Christian Leader," Archives de Sciences Sociales des Religions (1977).

${ }^{9}$ Russell L. Huizing, "Bringing Christ to the Table of Leadership: Moving towards a Theology of Leadership," The Journal of Applied Christian Leadership (2011).

${ }^{10}$ Christian Harrison and Christian Harrison, "Transactional Leadership Theory," in Modern Paradigms of Leadership, 2020.
} 
many services to be able to meet the different needs of its parishioners: ranging from public service that further facilitates the needs of the congregation in general. Elderly service, that the focus is on the needs of the elderly congregation. The young adults' service, more on workers or new families. Youth service filled with young children, such as students or high school children, as well as Sunday school services that focus more on children from birth to fourteen years old, depending on their respective churches.

This condition is different from most Indonesian churches in Australia because Indonesian churches in Australia start with the goal of meeting the spiritual needs of Indonesian settlers who come to Australia. If the congregation of migrants is a student, then in the range of four to five years, most of them will go for good back to Indonesia. Thus, most Indonesian churches in Australia do not have as many services as churches in Indonesia. Generally, an Indonesia church in Australia has only two services, public service and Sunday school service. Youth service is available in some churches that have enough number of running the youth service and family service separately.

Sunday school children are also part of the entire congregation in one church, so it is essential to have a pastor for these children. Sunday school children also have an interest, to keep getting spiritual intake for their spiritual development. Church leaders can directly come contact with Sunday school children or delegate Sunday school children's pastoral duties to their Sunday school teachers. So, it is necessary to have Sunday school teachers who have the heart of a shepherd. Who can act as a teacher, guide and also lead, both on Sundays - during Sunday school services, or on other days when needed, especially in times of pandemic.

\section{Characteristics of Sunday School Children}

Sunday school service is almost there in every church, in every denomination. Almost all the service is running every Sundays, where children are the most critical element of Sunday school. Children are human beings from birth until puberty ${ }^{11}$, from the time of conception until reaching the time of puberty ${ }^{12}$. The children are not miniatures of adults. They are human beings who will also become adults after going through several physical and mental developmental ${ }^{13}$. So the spiritual development and growth of Sunday school children become very important as same as the importance of their physical growth. Sunday school children are the best seed of church leaders that each church has for the development and existence of the church in the future ${ }^{14}$. Thus, the church must

\footnotetext{
${ }^{11}$ Mosby, Mosby's Dictionary of Medicine, Nursing \& Health Professions, Choice Reviews Online, 9th Editio., vol. 47 (Elsevier/Mosby, 2009).

${ }^{12}$ Spencer A. Rathus, Childhood and Adolescence: Voyages in Development, 5th ed. (Cengage Learning, 2013).

${ }_{13}$ Elsiebeth McDaniel and Larry Richards, You and Children (Effective Teaching Series) (Moody Press, 1973).

14 Tanto Kristiono and Deo Putra Perdana, "Hambatan \{Guru\} Dan \{Pelayanan\} \{Sekolah\} \{Minggu Di $\{$ Gereja $\{$ Kristen $\}$ Jawa $\{$ Jebres \{Surakarta\}," JURNAL TEOLOGI GRACIA DEO (2019).
}

maintain and provide the spiritual fulfilment that these children need.

In Sunday school, there is a division for all children who are in several different classes. This division is to provide more comfort in interacting between teachers and pupils, as well as between students. Here is the division of classes in Sunday school based on the age of the students. Toddler - up to five years old, primary - six to eight, secondary - nine to eleven, and teens - twelve to fourteen. The four classes above have differences in terms of handling and teaching. The reason is that the character of the child in his development will continue to change, and it requires a different way of teaching. Therefore, it is necessary to know the character of the child in each of these classes. Here are some characteristics of each age level, accompanied by practical input and application that can be done by the leader in the Sunday school class ${ }^{15}$.

Toddler, their characteristics are happy to run around and jump; then, the classroom must be spacious in order to meet their needs. Next, the ability to concentrate is concise and easy to feel weary; then, the delivery of the word does not take too long, enough 10-15 minutes. Furthermore, love familiar things and happy to repeat, the delivery of the story can be done over and over again. Lastly, learn through play, have many games.

Primary, their characteristics are, play in groups, use the type of game that requires cooperation. Next, still think then, avoid abstract words. Furthermore, their ability to read is getting more and more then, encourage them to read a book or Bible in the learning process. Finally, they are easily afraid and give up quickly then, give them a spirit and a feeling of safety.

Secondary, their characteristics are high creativity, provide creative learning activities. Next, starting to have logical thinking then, use teaching methods that can stimulate their logic. Next, love to ask then, try to give a satisfactory answer. Finally, they are easy to lose their patience and angry then they can be taught to be severe and withstand emotions.

Teens, their characteristics are: love to critique; then, it is necessary as a leader to have an understanding personality. Next, starting to able to think seriously, ask open questions so they can think more. Furthermore, they can memorize better but demanding a reason, teach them to start memorizing Bible verses by also giving accurate understandings that they can receive. Lastly, starting to have mood swings - erratic emotions, sometimes happy, sometimes grieving, the leader needs to understand and provide guidance periodically.

Pastoring of Sunday school children should pay attention to the characteristics of each protégé, at least from the age of the children. So by having the right understanding and by doing the right division, children will enjoy the Sunday school services. On the other hand, teachers will also be more manageable in mentoring and teaching the children of Sunday school.

\footnotetext{
${ }^{15}$ Frederika Lay, PAK Dalam Gereja Lokal (IMI, n.d.).
} 


\section{New Pandemic and New Normal of Pastoral Care}

The global pandemic period of the SARS-CoV-2 virus began on March 11, 2020, which was declared by the WHO. This status is reflecting the spread of the virus is very rapid even outside china, which reaches 13 -fold ${ }^{16}$. Actions must be taken by all countries, to slow the spread of this virus. Require everyone with the lowest symptoms to exercise self-isolation and require everyone to keep their distance. As keeping a distance between people is one effective way to reduce the spread, especially the spread of symptomless people ${ }^{17}$. The spread of this virus becomes very fast due to the way it is spreading, through the respiratory tract ${ }^{18}$. With a high level of effectiveness social distancing in suppressing the spread of the Covid-19 virus, many countries are doing this action very strictly. However, there is much to sacrifice from this action. Panic buying, so that many depleting essential goods in supermarkets. Events that gather many people, such as concerts and festivals, should be cancelled. Restaurants and cafés should close. Studying, working, and meetings are conducting online. Until there are no more shaking hands, cuddling is no longer even possible to stand next to each other 19.

Governments are restricting almost all organizations, and churches become one of the organizations that are also affected by it. The church, which is usually a gathering place for parishioners to build and strengthen each other, is also a place for teaching, guidance, and guidance. It is no longer possible to do during this pandemic period. As a result, adverse effects are resulting from too long when people only stay at home and can not meet their friends and siblings. In Australia, during this pandemic, the infection rate was very high between March 27 and April 7, 2020. Many people claim that they have a disorder of their mental health. $78 \%$ of 5070 adults stated that their mental health is getting worse. $25.9 \%$ stated they became terrified of being infected by the Covid-19 virus. $52.7 \%$ stated they are worried about their family and friends infected by the virus ${ }^{20}$.

During the ongoing Covid-19 pandemic, all houses of worship cannot freely open, as usual, either limited in number or should be closed in its entirety. A church pastor in this time must quickly and appropriately adjust the circumstances to keep fulfilling his pastoral duties, both to teach as well as to guide and lead. One way to continue to hold the service is to use the availability of online media technology as a means of online service. There is a large selection of online meeting

\footnotetext{
${ }^{16}$ Domenico Cucinotta and Maurizio Vanelli, "WHO Declares COVID-19 a Pandemic," Acta Biomedica, 2020.

${ }^{17}$ Joseph A. Lewnard and Nathan C. Lo, "Scientific and Ethical Basis for Social-Distancing Interventions against COVID-19," The Lancet Infectious Diseases, 2020

${ }^{18}$ Srinivas Murthy, Charles D. Gomersall, and Robert A. Fowler, "Care for Critically Ill Patients With COVID-19," JAMA 323, no. 15 (April 21, 2020): 1499, https://jamanetwork.com/journals/jama/fullarticle/2762996.

${ }^{19}$ Paul Atkinson, "Social Distancing," Design Journal, 2020.

${ }^{20}$ Jill M. Newby et al., "Acute Mental Health Responses during the COVID19 Pandemic in Australia," PLOS ONE (2020).
}

applications that can use to hold service, with various advantages and disadvantages of each. Microsoft Teams, Skype, Google Meeting, Cisco Webex, or Zoom Meeting are some of the many applications that can use. It reported that the increase in users of the online meeting service increased significantly during the Covid-19 virus pandemic. However, there are no exact figures for the increase in Zoom Meeting users is the highest and Microsoft Team users are increasing by $70 \%{ }^{21}$.

Zoom Meeting, commonly known as Zoom, founded in 2011, is headquartered in San Jose, California, United States. Zoom have capabilities to communicate via video and audio and chat, either through a computer or on mobile devices such as mobile phones and also tablets ${ }^{22}$. There are various packages to choose as an online meeting support facility, ranging from one that can be used free of charge, with a time limit of forty minutes. Next, with no time limit, ranging from A $\$ 209$ per year for a maximum of 100 people, A $\$ 279$ per year, with a maximum of 300 people, to options with a maximum of 500 people or more that can obtain by contacting Zoom directly. Another facility that can use in Zoom is the breakout, where it is beneficial to provide discussion rooms during two or more meetings at the same time.

With various packages in Zoom meeting, the church can choose which package that suit with its needs also its financial condition. For example, for churches with less financial support, they can use the free package with good time management. They can create few sessions those up to 40 minutes such as praise and worship, sermon and after sermon session. Then once a session finish, they can create a new session and ask their congregation to re-join.

To keep up with the spiritual needs of the congregation, so do Sunday school children. The church where this research took place chose to use Zoom Meeting to perform online worship every week, worker meetings, and also for cell group activities. The same choice for the Joy Kids - a Sunday school service in the Place of Joy church, to also use the Zoom Meeting as an online medium to perform Sunday school services.

\section{Procedures and Adjustment of worship time}

During this pandemic, several different actions taken to run Sunday school children, at Joy Kids. By trying to maintain existing habits even though it is online. The most striking difference is to transfer Sunday school hours from Sunday morning, at the same time as the public service in the church, to Saturday afternoon. These changes happened after several Joy Kids services held on Sundays at the same time or preceding public service, does not provide satisfactory results, either for the students as well as for the parents. As to keep children focus while doing worship using the online system, it

\footnotetext{
${ }^{21}$ Tom Warren, “Zoom Admits It Doesn't Have 300 Million Users, Corrects Misleading Claims - The Verge," The Verge.

${ }^{22}$ Zoom, "Video Conferencing, Web Conferencing, Webinars, Screen Sharing - Zoom," Zoom (2019).
} 
requires help and support from the parents of children, especially for children at the age of toddlers. Thus, what happens during Sunday school services is held along with public worship online, it is challenging to get the children's attention. Another supporting reason is that children are not familiar with worship online, as it is unprecedented. According to parents, the children also have the same problems as online learning in the early days of this pandemic. The other time arrangement before Saturday afternoon was Sunday morning before the public service. However, this arrangement was not giving a good result too, as many children cannot wake up early. So, many of them were coming late or even not attending the full service.

To maintain the taste and sensation of worship at Joy Kids, the way of worship that is usually done face-to-face in the church strives to be maintained. As such, the first forty minutes, usually filled with praise of worship and preaching, are still performed even online. The way used to perform worship compliments becomes somewhat different when previously, there were always music players who helped to accompany the leader of the praise. During this online service, the praise leader will perform a video of the song, usually three songs, two compliments, and one worship before preaching. Then, the video is displayed using a share screen facility, and the hymn leader sings along with the video to encourage the children. It would be better if the prepared song video comes with lyrics to help the children in singing. When finished with the praise and worship, the leader will remind the children to be able to give offerings as they usually do in church. Only during online worship, they can ask their parents for help sending their offerings through the church's bank account. At the same time, children also taught to understand what is offerings and what is tithes.

Next, enter into the sermon, where aspects of teaching in pastoring carry out. The delivery time of the sermon is limited to fifteen to twenty minutes to keep the concentration of the children, while interspersed with funny and exciting things to get the children's attention back. Like, fun experiences related to preaching themes, funny stories that are also related to the theme of preaching, or can also greet children by directly calling their names. Images can also support preaching, that can display through the share screen facility. Using English as the introductory language, and selected words or diction that are easy to understand even for the youngest children. A short movie can also use to help children to get understanding. This action is to ensure that from the youngest child at the toddler level to the children at the primary level can understand the words conveyed in the sermon. As if with face-to-face service, language differences help with gestures, then it is not the case when worship running online. In the time, after finishing the sermon, prepared some questions that can be answered by the children. These questions are to ensure once again that the children truly understand the content of the sermon delivered. Most children at the primary level will be very enthusiastic in answering. At the same time, toddlers are less likely, as well as children who are at the same level. Therefore, after the sermon finish, the children will bring into classes based on their age level.

In this time of the pandemic, there need to be ordinances and time adjustments in the pastoral care of children. The service is running online, so there is no more face-to-face as before the pandemic period. Also, the service time needs to adjust to the needs of children and parents. Nevertheless, still maintaining the flow of worship as before the pandemic period.

\section{Mentoring Methods}

In classes, they will be guided and led by teachers, who are already preparing to discuss and emphasize the sermons. So it can share more powerfully and with more understandable language at every age level. In the toddler's class, the teacher will return to tell a story and prepare a game or activity that can help the child in understanding the theme of the preaching of the day. Here toddlers will be more expressive because they feel comfortable only with friends their age and with mentor teachers they also already know. The difficulty faced in this class is usually the loss of concentration of children very quickly. Therefore the teacher who teaches here must be very expressive, actively doing many things. Like calling each child's name periodically, using the virtual background facilities that are in Zoom, to replace the background of the image with an image that is interesting for the child. While in the primary class, teachers will prepare more discussion materials to stimulate children to think while gaining an understanding of the given sermon. Also, to deliver the discussion materials, teachers can use online quiz facilities, to re-repeat the discussion of preaching. This method is exciting for children, certainly with questions that are more weighted than questions in question sessions after sermons. The usual quiz facility is Kahoot. These classes are not time-limited, yet teachers can end classes after a particular time. Since most teachers who teach are students or housewives, they must complete their tasks as well after serving in Joy Kids Sunday school. Often, children can enjoy their meetings with their teachers and their friends in these classes. So, they can stay last longer in their classrooms and even spend their dinner together.

Parental support and assistance are essential during this pandemic period, for the continuity of this online worship. Similarly, in the days before the pandemic, Sunday school teachers continued to connect with parents. By using WhatsApp group facilities, the leader will group the parents per age level of their child. In this group, teachers can share materials that can be printed by parents to be used during the learning process to teach in their child's Joy Kids class. The teacher can also report the children's progress to their parents, how their children behave and what the parent can re-discuss at home regarding the sermon. Here parents can also provide feedback and questions about their children's worship and needs. 
In the early days of the beginning of this online worship, parental assistance was indispensable for every child. Even after a long walk, the presence of parents is still needed, especially for children who are the age of toddlers. As they are easy to lose their concentration so, there must be someone who is also with them. If during Sunday school services in the church, the teachers are accompanying the children, then when at home, it is the parents who can replace the role. Therefore, the teacher parents relationship is meaningful so, they can keep supporting each other, especially during the online service.

During the pandemic, kids mentoring is carrying out without face-to-face. However, there remained a need for the class division after worship, intending to be able to deepen the children's understanding of the given sermon. Many ways can use, tailored to the characteristics and needs of the child. Also, parental support is indispensable during the online mentoring process during this pandemic period.

\section{CONCLUSION}

From the discussion and results of the study can be drawn several conclusions:

Firstly, Sunday school children are also part of the entire congregation in one church. So, crucially, the role and pastoral duties are also applied to school children this week. So it is necessary to have Sunday school teachers who have the heart of a pastor, who can act as a teacher, guidance, and leader.

Second, pastoral care of Sunday school children should pay attention to the characteristics of each protégé, at least from the age of the children. Thus, children will enjoy Sunday school services as a participant. Teachers will also be more manageable in leading and teaching Sunday school children.

Third, during the pandemic period, Sunday school services are conducted online using facilities and technology to conduct meetings online, using the Zoom Meeting and Whatsapp as support. Also, for churches with limited financial support, online services can run in a few session with good time management, by keeping each session only up to 40 minutes.

Fourth, in this pandemic, there need to be ordinances and time adjustments in the pastoral care of children. By maintaining the flow of worship as before the pandemic period yet, worship becomes different, performed online, and hours of worship also need to be adjusted.

Fifth, mentoring is doing online, without face-to-face during the pandemic period by splitting the children into different classes after worship. The aim is to deepen children's understanding of the delivered preaching, which can be done in a variety of ways and with the support of parents. Also, giving time for the children to meet and play with their friend, who is the same age range with them. 